\title{
Between the gift and the market: the economy of regard
}

By AVNER OFFER

$\mathrm{T}$ he original insight of economics is contained in Adam Smith's account of the efficiency of an impersonal market, in which every individual seeks his own advantage, with no regard for the welfare of others. Polanyi posited a 'great transformation', from socially embedded reciprocity, to impersonal price-driven market exchange, which he saw as culminating in late eighteenth-century Britain. ${ }^{2}$ This trajectory is disputed by writers who identify pervasive market exchange in antiquity, the early middle ages, and pre-modern Africa. ${ }^{3}$

What is less noted is the persistence of non-market exchange into modern times. Goods and services continue to be transferred without the benefit of markets or prices, to be exchanged as gifts. There are unilateral transfers in the form of organ donations, charity contributions, and bequests. There is an important non-profit sector, providing 4 per cent and 7 per cent of employment in Britain and the United States respectively. 4 Most gifting, however, takes place in a context of reciprocity. Foremost is exchange within the household. But gift giving also motivates much retail purchasing. Reciprocity abounds at work; it affects management, agriculture, marketing, entrepreneurship, and politics. It mobilizes resources for growth, and is also implicated in corruption and crime. The persistence of non-market exchange on such a scale indicates that gifting may be, if not always 'efficient' in the formal sense, at the very least a viable alternative to the market system. This preference, it is argued here, arises out of the intrinsic benefits of social and personal interaction, from the satisfactions of regard. Prices facilitate exchange when information is scarce and coordination difficult, when goods are standardized and cheap. The market works best when the efficiency of production runs ahead of the efficiency of cognition and communication. It economizes on costly information. That was Hayek's key insight. ${ }^{5}$ Conversely, reciprocal exchange has been preferred when trade involves a personal interaction, and when goods or services are unique, expensive, or have many dimensions of quality. This study examines the dynamics

\footnotetext{
1 Thanks to Rebecca Abrams, Tony Atkinson, Yoram Barzel, Joanna Bourke, Chris Davis, Robert Frank, José Harris, Harriet Jackson, Heather Joshi, Robin Mason, Katharine Massam, Martin Spät, Todd Shaiman, Julia Twigg, Joachim Voth. Also to seminar and conference participants at Oxford and Venice. Special thanks to Robert Allen, Annie Chan, Paul David, Diego Gambetta, and Pramila Krishnan. The usual disclaimers apply even more than usual.

${ }^{2}$ Polanyi, Great transformation; also idem, 'Economy as instituted process'.

${ }^{3}$ Anderson and Latham, eds., Market in history.

${ }^{4}$ Rose-Ackerman, 'Altruism, non-profits and economic theory', p. 705.

${ }^{5}$ Hayek, 'Use of knowledge in society'.
} 
of reciprocity. It indicates why and to what extent 'the great transformation' into market exchange remains incomplete, and why, in some areas, it has even retreated.

\section{I}

Accounts of gift exchange abound in the literatures of anthropology and development. Mauss analysed the potlatch, a periodic feast of Indian tribes in the Pacific Northwest, as a status competition in generosity and waste. ${ }^{6}$ Malinowski described the long sea voyages undertaken by South Pacific islanders to trade decorgative sea shells in the kula system of gift exchange. ${ }^{7}$

From the ethnographic record, the following pattern emerges. Exchange begins with a transfer, for which reciprocity is expected. Reciprocity is usually delayed. Both the value of the reciprocal gesture, and its timing are left to discretion, though often regulated tightly by convention and custom. When the exchange is completed, a new sequence can begin. Take the practice of hospitality. The middle-class exchange of dinner invitations, and the small gifts that accompany them, are an example of delayed reciprocity. Reciprocity can also be indirect, with no return from the beneficiary (who may be unknown), but a credit with the community, to be reciprocated at some other time and place. Unconditional hospitality to total strangers was the norm in many parts of the Mediterranean, Arab, Iranian, and Indian worlds. ${ }^{8}$

In neoclassical market exchanges personal acquaintance is immaterial. The gains from trade are all the gains there are. Every sale is simultaneously a purchase. Any delay is priced by means of an interest rate. In contrast, in the gift exchange, the price is indeterminate. 'Delivery' and 'payment' can be separated by the exercise of discretion and the passage of time. Something else is acquired, over and above the material gains from trade. Exchange is not only an economic transaction, it is also a good in itself, a 'process benefit', ${ }^{9}$ usually in the form of a personal relationship.

Personal interaction ranks very high among the sources of satisfaction. ${ }^{10}$ It can take many forms: acknowledgement, attention, acceptance, respect, reputation, status, power, intimacy, love, friendship, kinship, sociability. To wrap it all into one term, interaction is driven by the grant and pursuit of regard. In The theory of moral sentiments, Adam Smith described the purpose of economic activity as the acquisition of regard.

What is the end of avarice and ambition, of the pursuit of wealth, of power, and preheminence? Is it to supply the necessities of nature? The wages of the

\footnotetext{
${ }^{6}$ Mauss, Gift.

${ }^{7}$ Malinowski, Argonauts of the westerm Pacific.

${ }^{8}$ Abraham's welcome to the angels, Genesis, XVIII; rural Greece today, du Boulay, 'Strangers and gifts'; Iran, Simpson-Herbert, 'Women, food and hospitality'; Yemen, Gingrich, 'is wa milh: Brot und Salz'; India, Khare, 'Indian hospitality'; discussion, Pitt-Rivers, 'Stranger, guest and hostile host'.

${ }^{9}$ Gershuny and Halpin, 'Time use'.

${ }^{10}$ Argyle, 'Subjective well-being', describes experimental and survey data. 
meanest labourer can supply them ... what are the advantages which we propose to gain by that great purpose of human life which we call bettering our condition? To be observed, to be attended to, to be taken notice of with sympathy, complacency, and approbation, are all the advantages which we can propose to derive from it. ${ }^{11}$

The propensity for 'sympathy' which dominates The theory of moral sentiments performs the same role, in motivating gift exchange, as the propensity to 'truck, barter, and exchange' performs for the market economy in The wealth of nations.

What is the relation between 'gift' and 'regard'? Regard is an attitude of approbation. It needs to be communicated. The gift embodies that communication and carries the signal. Trade in regard is vital: self-regard is difficult to sustain without external confirmation. The gift can be dear or cheap, substantive or symbolic. It is not costless. At the very least, 'regard' is a grant of attention, and attention is a scarce resource. ${ }^{12}$ The capacity for regard is constrained by the limited endowment of time and psychic energy. Withholding regard signifies indifference and rejection. Ostracism, the silent treatment, 'sending to Coventry', or solitary confinement, are among the harshest punishments. ${ }^{13}$ As Adam Smith put it, 'compared with the contempt of mankind, all other evils are easily supported'. 14

Gift exchange has two elements: the gains from trade, and the satisfactions of regard. The efficiency attributes of gift economies arise from the combination of these elements. This is suggested by analogy with the economic model of perfect price discrimination under monopoly (figure 1) ${ }^{15}$ In this model, the supplier is able to charge each buyer as much as, and no less than, that buyer is willing to pay, or in other words, not the marginal cost, but a price corresponding to that buyer's position on the demand curve. For each buyer, the exchange value equals the use value. The revenue curve $\mathrm{Pr}^{\prime}$ overlaps with the demand curve. There is no consumer surplus. All the surplus (striped area) goes to the monopolist. Under perfect price discrimination, both total output and surplus are the same as in the competitive market, i.e. production is just as efficient.

For this to happen, two conditions must be satisfied: the monopolist must know each buyer's maximum price, and there can be no arbitrage: buyers cannot trade with each other. These conditions are rarely met in an impersonal market economy, but they are common in reciprocal exchange. Every provider is a monopolist of his own regard. No one else can supply it. Hence it cannot be traded among recipients. The prerequisite of being able to divine the buyer's maximum price is more difficult to satisfy. Like a seller in market exchange, the giver of regard needs to

\footnotetext{
${ }^{11}$ Smith, Moral sentiments, 1, ch. ii.1, p. 50.

12 Gifford, 'Allocation of entrepreneurial attention'.

${ }^{13}$ In marital contexts, see Gottman and Levenson, 'Social psychophysiology of marriage', pp. 1845; Komarovsky, Blue-collar marriage, chs. 6-7; Hite, Hite report, pp. 15-26; Rubin, Worlds of pain, pp. 115-25.

${ }^{14}$ Smith, Moral sentiments, p. 61.

${ }^{15}$ Suggested by Robert Allen; Frank, Microeconomics and behavior, pp. 393-5.
} 
ascertain his partner's preferences from the outside. Like the seller in market exchange, he has a strong interest in getting it right. Like the market seller, he often gets it wrong. But when the face-to-face interaction is repeated, there is an opportunity to tune regard to the partner's needs. This partner cannot trade in this regard with anyone else: he can only reciprocate with the original provider. Under perfect price discrimination, all the surplus goes to the monopolist. In reciprocal exchange, the original provider acquires a credit, and when reciprocity begins, the two protagonists take the surplus alternately. In the long term, therefore, the exchange value will approximate not to the use value (expressed by the demand curve) but to the market value (figure 1). This similarity suggests that reciprocity can be an efficient means of exchanging goods and services. The initial gift may be driven by an impulse of regard, by the desire to elicit regard, or by both. The fear of losing regard provides a strong incentive to continue. Repetition is self-enforcing. The penalty for failure is exclusion.

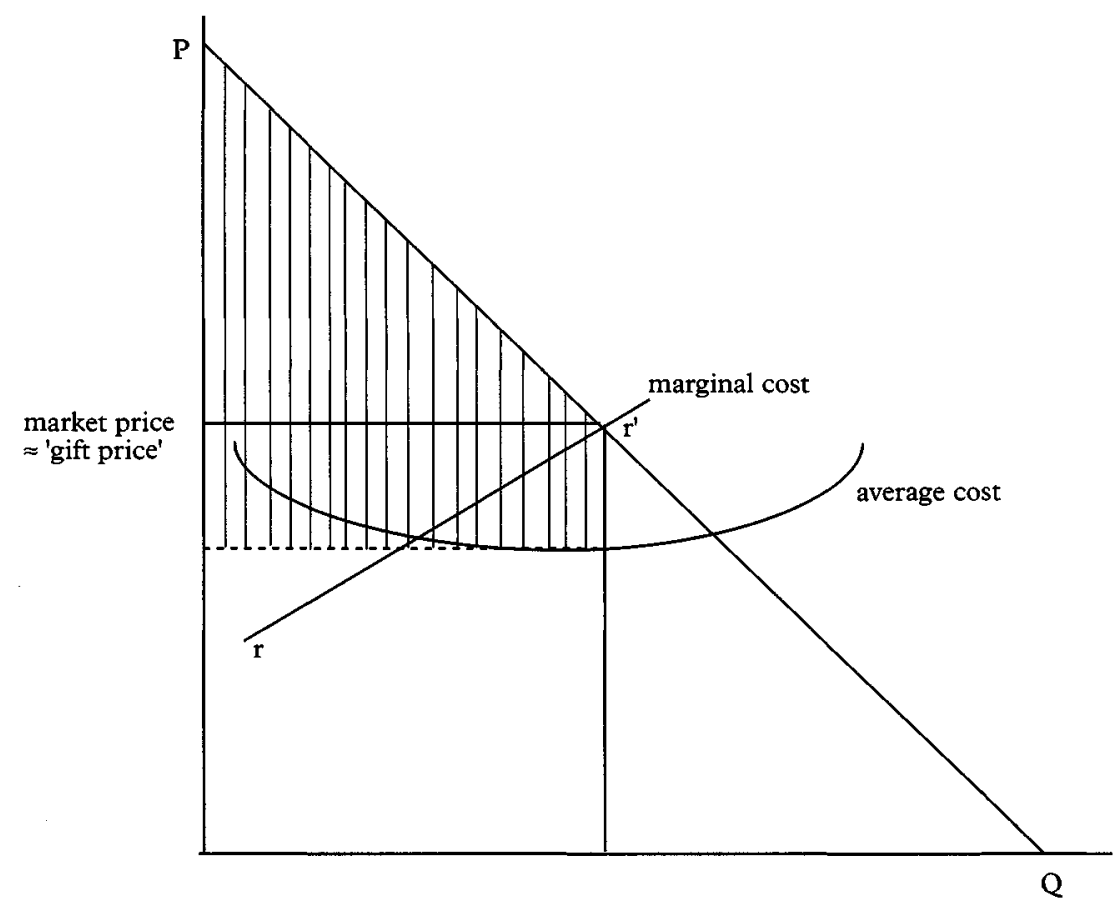

Figure 1. Gift exchange as perfect price discrimination Note: $\mathrm{rr}^{\prime}$ is the marginal cost curve

Equilibrium is not easy to find. In a study of dating in the United States, some gifts sustained the bond, but others led to misunderstanding, disappointment, and unwelcome obligations. ${ }^{16}$ Experienced partners can form a judgement on preferences, trustworthiness, and credibility. ${ }^{17}$ Trust

\footnotetext{
${ }^{16}$ Belk and Coon, 'Can't buy me love'.

${ }^{17}$ Frank, Passions within reason. 
itself resembles a gift: a unilateral transfer with the expectation, but no certainty, of reciprocity. Regard provides a powerful incentive for trust, and trust is efficient: it economizes 'on the 'transaction costs' of monitoring, compliance, and enforcement. ${ }^{18}$ Regard may be seen as a 'transaction benefit'.

In one respect, the economy of regard pervades all human interaction. Language is a vehicle of regard, and conversation is a gift economy, loaded with cues of acceptance or disdain. ${ }^{19}$ The normal pleasantries, 'please', 'thank you', and 'good morning', are all statements of regard, their withholding hinting at rejection. Beyond language, non-verbal cues communicate intensities and qualities of regard; the smile, like scores of other gestures, is universally understood. ${ }^{20}$

Real regard is typically not for sale. There is widespread reluctance to use money as a gift. Some goods are devalued if paid for in cash: a lover's devotion, a friend's companionship. Others are enhanced if given voluntarily: a temporary loan, expert opinion, a cooked meal, used clothing. The retail boom at Christmas is almost entirely based on this reluctance to use cash directly in gift exchange. ${ }^{21}$ Often, the convenience of money makes it the preferred medium for a gift. In this case money is often 'disguised', in elaborate gift wrapping, as at the Chinese New Year, or even in a plain envelope. Money is also personalized by 'earmarking', which constrains its fungibility. Book tokens and department store vouchers endow money with the semblance of a gift. ${ }^{22}$ When money is given, its transfer is circumscribed by strict rules. In 'Middletown', Indiana, in 1978, money transfers at Christmas were used as a gift only from senior to junior kin, and very rarely in any other way. ${ }^{23}$

Why is money so persistently avoided? To have value, regard must be authentic, i.e. unforced. Hence, in reciprocal exchange, discretion is not only allowed, but is actually required. A money gift is impersonal: too much like a wage. ${ }^{24}$ Cash is fungible and faceless. In business, the vendor's regard for customers is often perceived as inauthentic, as a pseudoregard. ${ }^{25}$ The customers have reason to suspect it doesn't matter who they are. A gift, on the other hand, is personalized. Even when obtained from the market, it provides evidence of an effort to gratify a particular individual. It conveys a signal that is unique to giver, receiver, or both. The personalization of gifts, with its evidence of caring, serves the function of authenticating the regard signal. ${ }^{26} \mathrm{~A}$ gift without regard would be a bribe.

\footnotetext{
${ }^{18}$ A pioneer study in this vein is Ben-Porath, ' $\mathrm{F}$-connection'.

${ }^{19}$ Lojkine, 'Valeur, valeur d'usage et valeur symbolique'; Dunbar, Grooming, gossip.

${ }^{20}$ Ekman, ed., Emotion in the human face; idem, Telling lies.

${ }^{21}$ Burgoyne and Roth, 'Constraints on use of money'; Belk and Coon, 'Can't buy me love'; Webley and Wilson, 'Unacceptability of money as a gift'; Webley and Lea, 'Partial unacceptability of money'; Cameron, 'Unacceptability of money as a gift'; Gonul, 'Is money an acceptable gift in Cyprus?'.

${ }_{22}^{2}$ Zelizer, Social meaning of money, ch. 3.

${ }^{23}$ Caplow, 'Rule enforcement without visible means', p. 1315.

${ }^{24}$ Zelizer, Social meaning of money, pp. 91-9.

${ }^{25}$ Hochschild, Managed heart.

${ }^{26}$ Inspired by discussion with Diego Gambetta; Carrier, Gifts and commodities, ch. 8.
} 
Reciprocity is not all pleasure: like the market, it produces 'bads' as well as goods. Giving gives rise to obligation, in other words, a debt: the giver notches up an emotional and material credit, in the form of a bond on the recipient. The term bond will be used to signify a repeated exchange of regard. It applies here in three senses. Like a financial bond, it has some features of a contractual obligation. Like the human bond, it is an emotional link. The term bond is also used in the sense of a fetter, as a form of oppression: 'With gifts you make slaves', an Alaskan Inuk is reported as saying. ${ }^{27}$ Competitive exchange in which gifts are reciprocated with a premium can drive the weaker party into permanent subordination. ${ }^{28}$

The obligation to reciprocate is typically a burden, which can only be relieved by means of a return gift. Asking for help is psychologically difficult, ${ }^{29}$ and so is the obligation to reciprocate. ${ }^{30}$ Excessive intimacy can be stressful. A gift without reciprocity vexes both giver and receiver, as in beggary, or some forms of religious almsgiving, such as the unilateral donations of dana in Benares, India. ${ }^{31}$ The gift signal can be rejected or misconstrued. Instead of a benign cycle of exchange, we get a spiral of insult, hate, and retribution, which may be difficult to break. Pathological gift cycles are expressed in such historical institutions as the duel, the blood feud, and the crime of passion. A modern equivalent is the painful spiral that leads on to divorce. The anonymity of the market confers an immunity from such bonds, it 'economizes on love'. ${ }^{32}$

Where does regard come from? Computer tournaments suggest that positive regard confers an evolutionary advantage, that 'nice' is better than 'nasty'. ${ }^{33}$ Regard promotes sociability, and sociability facilitates cooperation. It breaks the deadlock of prisoner's dilemma with a norm of first-mover cooperation. 'Reciprocal altruism' is widely observed in animal species. It is easy to imagine the capacity for regard as being selected in human evolution for its survival benefits. ${ }^{34}$ Hunting-gathering involves foraging over large areas, with occasional substantial windfalls (e.g. a large mammal), which are more than a single hunter could either capture or consume. Regard promotes sharing. The households of the Ache people of eastern Paraguay, for example, derive more than 70 per cent of their food through sharing with others, and those who provide more than their share gain prestige. ${ }^{35}$ It is reasonable to assume that the capacity for regard, like the capacity for language, is innate, even if the forms that it takes are culturally specific. ${ }^{36}$ On this interpretation regard

\footnotetext{
${ }^{27}$ Kelly, Foraging spectrum, p. 167.

${ }^{28}$ Mauss, Gift, p. 37.

${ }^{29}$ Krishnan, 'Recipient need'.

${ }^{30}$ Farber, 'Limiting reciprocity among relatives'; Bourdieu, 'Les modes de domination'.

${ }^{31}$ Gmelch and Gmelch, 'Begging in Dublin', pp. 450-2; Parry, 'On the moral perils of exchange'.

${ }^{32}$ Robertson, 'What does the economist economize?'

${ }^{33}$ Axelrod, Evolution of co-operation. These are his terms.

${ }^{34}$ Trivers, Social evolution, ch. 15, esp. pp. 386-9.

${ }^{35}$ Kelly, Foraging spectrum, ch. 5.

${ }^{36}$ Pinker, Language instinct, pp. 412-5; Brown, Human universals; Cosmides and Tooby, 'Cognitive adaptations for social exchange'; Lojkine, 'Valeur, valeur d'usage et valeur symbolique'.
} 
arises from an innate propensity which we wish to satisfy by means of giving and receiving. The positive emotions (unlike the negative ones) are easy to fake. ${ }^{37}$ The ability to fake regard facilitates gift exchange, but it also places a premium on material authentication, i.e. on gifts.

Even unilateral or asymmetric transfers are not entirely disinterested. The giver hopes for regard from the younger generation, or aspires to a lasting reputation. Such transfers may also have insurance attributes: by treating others with consideration, we uphold a norm of mutual support. But the existence of 'pure gifts', for instance in the case of 'giving by stealth', confirms the existence of a positive impulse of regard. ${ }^{38}$ The existence of such an impulse is necessary to endow the gift exchange with credibility.

Gift exchange is not easy to model. ${ }^{39}$ As in repetitive bargaining generally, there is no unique equilibrium, although the outcome ought to reflect the 'terms of trade', the prior endowment of the two parties and their consequent 'bargaining power'. ${ }^{40}$ These 'terms of trade' can be steeply asymmetric. One difficulty in modelling is that regard is intangible, and hence the 'visible' terms of trade in commodities may fail to capture the 'real' terms of trade, including regard. There is no reason why a single exchange should be Pareto-optimal, although repetitive reciprocity ought, like its market analogue, to converge onto a contract curve. At the same time, the casual evidence for regard motivation is pervasive and compelling. It is supplemented by the experience of non-cooperative game playing in experimental economics. Prior face-to-face interaction, even very brief, will incline participants towards more cooperative strategies. This is not predicted by axiomatic game theory. ${ }^{41}$ Other evidence comes from 'ultimatum' games, in which pairs of players are invited to divide a sum of money between them. The first player has to offer a share to the second player. If the offer is rejected, the money is forfeited. Game theory predicts that any offer ought to be accepted, as being better than nothing. In actual play, offers of less than 20 per cent tend to be rejected, the average division hovers around one-third, and many players offer 50 per cent. While high share offers cannot be interpreted exclusively as fear of rejection-they are usually described as a preference for fairness-the rejection of low shares is consistent with avoidance of insult. ${ }^{42}$ Face-to-

\footnotetext{
${ }^{37}$ Ekman, Telling lies, pp. 36, 86, 126. Happiness is a positive emotion, anger a negative one.

${ }^{38}$ Collard, Altruism and economy; Zamagni, Economics of altruism; Stark, Altruism and beyond; McLean and Poulton, 'Good blood, bad blood'. But if this impulse is satisfying, can it be devoid of self-interest?

${ }^{39}$ See e.g. Smith and Boyd, 'Risk and reciprocity'; Dasgupta, Well-being, pp. 324-42; also for various models, Landa, Trust, ethnicity and identity.

${ }^{40}$ See e.g. Kreps, Course in microeconomic theory, ch. 15.

${ }^{41} \mathrm{~A}$ list of references is in Ostrom, Gardner, and Walker, Rules, games and common-pool resources, p. 149.

${ }^{42}$ See e.g. Thaler, Winner's curse, ch. 3; Frank, Passions within reason, pp. 170-4. The outcomes are influenced by occupational and ethnic background. A recent survey of research is Roth, 'Bargaining experiments', pp. 253-92.
} 
face appeals also improve the response for charity appeals, street beggars, and hunter-gatherers. ${ }^{43}$

Here are the features of the gift so far: it is a voluntary transfer; an expectation of reciprocity; reciprocity is notionally open to discretion as to value and time; and is motivated by a desire for regard; over and above any gains from trade; regard is communicated by gift; personalized gift authenticates regard; gift is unpriced, often unpriceable; and gift establishes repetitive, self-enforcing bond, which facilitates trade.

The sections that follow indicate how reciprocity has maintained or even extended its sway in several substantial domains, during the process of modern economic growth.

\section{II}

Reciprocity (direct and indirect) has pervaded scores of pre-industrial societies. In pastoral and agrarian settings, it was used to reduce the variance of food supplies, to allocate resources over time, and to share risks. ${ }^{44}$ It also expressed inequalities in social position and power. Fiske distinguishes three types of non-market exchange. ${ }^{45}$ Extrapolating from his model, communal sharing is the joint exploitation of a resource, as often practised in foraging. In authority ranking, distribution is governed by rank: relations are paternal and exchanges are asymmetric. This is often a form of indirect reciprocity. Elders, chiefs, or landowners collect tribute, which enforces a level of production substantially above subsistence. Authority and prestige are then underpinned by displays of generosity. The inability to reciprocate perpetuates subordination. ${ }^{46}$ Equality matching is an exchange between equals.

In pre-industrial societies, the intensity of obligation is inversely related to kinship. ${ }^{47}$ The family can provide good protection at lower cost than capital markets, because of the low risk of default. ${ }^{48}$ Default is minimized by the value placed on family regard, and the ability of parents to control bequests. ${ }^{49}$ The family retains a grip over migrants, who send remittances for long periods of time. 'Remittances are of a gigantic magnitude', as a source of foreign exchange in several large countries, including Pakistan, Egypt, Turkey, Portugal, and Yugoslavia. ${ }^{50}$ Beyond the nuclear family, gifting fulfils some of the functions of insurance, financial, and welfare systems. Relatives, friends, and neighbours lend their support both for investment and in adversity. In Asian mercantile families a successful

\footnotetext{
${ }^{43}$ R. Freeman, 'Give to charity?-well, since you asked', unpublished paper, LSE conference on the economics and psychology of happiness and fairness, 4-5 Nov. 1993; Peterson, 'Demand sharing'; Gmelch and Gmelch, 'Begging in Dublin'.

${ }^{44}$ e.g., Cashdan, ed., Tribal and peasant economies; Finley, Ancient economy, pp. 150-2; Reynolds, Kingdoms and communities, pp. 148-54.

${ }^{45}$ Fiske, 'Relativity within Moose ("Mossi") culture'.

${ }^{46}$ e.g. the fajmani caste system in India: Dasgupta, Well-being and destitution, p. 237.

${ }^{47}$ Sahlins, Stone age economics; Lucas and Stark, 'Motivations to remit'.

${ }^{48}$ Kotlikoff and Spivak, 'Family as annuities market'.

${ }^{49}$ Bernheim, Shleifer, and Summers, 'Strategic bequest motive'.

${ }^{50}$ Stark, Altruism and beyond, p. 89. 
entrepreneur was often obliged to share with large numbers of relatives, and similar assumptions were sometimes implicit in relations within Jewish families in eastern Europe. ${ }^{51}$

Families remain the wellspring of regard. They are held together by two intense bonds: between spouses and between the generations. In preindustrial societies family formation was preceded by exchanges of dowry or brideprice, which played a variety of roles in reciprocity webs. ${ }^{52}$ The routines were strictly prescribed. Modern family formation is more discretionary, and hence conforms more closely to our voluntary model of gift exchange. In modern courting and romantic attachment, the road to intimacy is a spiral of mutual self-disclosure, an exchange of information and gifts. ${ }^{53}$ It leads to erotic interaction, a potent form of bonding. Sexual exchange used to be a prime incentive for marriage, and it remains the case that marriage partners have intercourse much more frequently than those living alone..$^{54}$

In pre-industrial agrarian and craft societies, household production accounted for the vast bulk of output. The share of total output taken by agriculture has contracted sharply, but the household economy remains very substantial. Its scale is captured by 'extended national accounts', which incorporate household production in national output, by assigning it a notional wage extrapolated from women's paid labour. The use of shadow wages is reasonable. It is this, at the margin, that women sacrifice when deciding to stay at home. In these estimates, household labour amounts to between one-quarter and more than one-third of national product (figure 2). The level fluctuates a little, and has some cyclical components (it moves inversely with the market economy). In Australia, for example, household production has remained a high proportion of the economy over two centuries, producing an average of 36 per cent of 'gross community income' (i.e. the sum of market and household income) for the whole period 1860 to 1990 , and only a very slight decline from 38 to 35 per cent (exponential trend) over the whole period. ${ }^{55}$ American and British estimates are lower. Household production is highly labour intensive. An input-output analysis in Australia in 1975-6 indicates that 70 per cent of household inputs are represented by labour, another 22 per cent by materials and energy, and only 8 per cent by equipment and housing. ${ }^{56}$ Although household production has remained labour intensive, its output remains (like many other services) a superior good. It remains in demand, and can maintain or sometimes increase its share of national output.

\footnotetext{
${ }^{51}$ Hwang, 'Face and favor', p. 950; Bellow, 'Old system'.

${ }^{52}$ Dixit, 'Bride-price and dowry'; Gregory, Gifts and commodities, pp. 63-7.

${ }^{53}$ Rubin, 'Lovers and other strangers'; Altman, 'Reciprocity of interpersonal exchange'; Belk and Coon, 'Can't buy me love'.

${ }^{54}$ Humphries, Secret world of sex, pp. 32-4 and ch. 4; Michael et al., Sex in America, ch. 6. Cohabitees have sexual intercourse more often than married people, but are a much smaller fraction of the population.

${ }^{55}$ Snooks, Portrait of the family, p. 17, and tab. 7.2, pp. 166-7.

${ }^{56}$ Ironmonger, Households work, tab. 2.3, p. 30.
} 


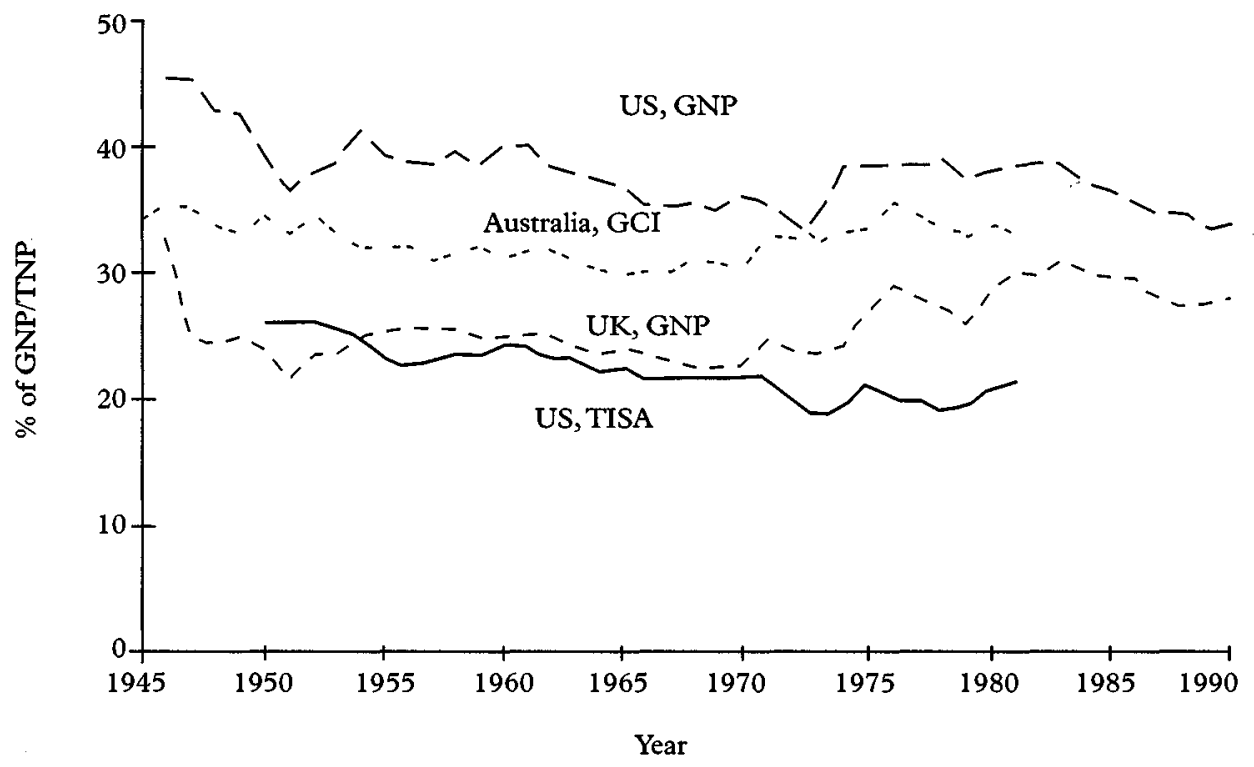

Figure 2. Household production as percentage of national product

Sources: US, GNP: Bureau of Economic Analysis, in Eisner, Total incomes system, tab. A.15, p. 73; Australia, GCI (gross community income: sum of market, household, and public sector production), in Snooks, Family within total economy; tab. 7.2, p. 167; UK GNP: Jackson and Marks, Measuring sustainable economic velfare, app. A, pp. 3942; US, TISA (total incomes system of accounts): Eisner, Total incomes system, tab. A.15, p. 73

Shifting our gaze from women to men, history indicates a positive shift away from the market and into the household. Typical male working hours have fallen drastically since the nineteenth century; from 65 hours a week for average full-time work in Britain in 1856, to 42 hours in $1973 .{ }^{57}$ Most of this time has been transferred into the home. Nordhaus and Tobin have attempted to impute a value to leisure time (and nonmarket activity) in their set of extended national accounts (figure 3 ). If a price is placed on free time, this value dominates the flow of welfare. In figure 4, leisure has contracted in comparison with GNP since the 1930s. Part of the effect is cyclical, representing the shift to full employment between the 1930s and the 1960s. On the other hand, 'non-market activities' (mostly housework) have generally kept up with the growth of GNP, rising from 42 per cent in 1929 to 48 per cent in 1965. These two sets of data indicate the shifting boundaries of the gift economy. In terms of time alone the shift out of market work has continued for men in the last two decades, while women's participation has increased in some countries, and remained stable in others. ${ }^{58}$ All in all, time spent in paid employment in a 17-country 'world' between the 1960s and the $1980 \mathrm{~s}$, for women as well as men, amounted to only 21 per cent of the

\footnotetext{
${ }^{57}$ Matthews, Feinstein, and Odling-Smee, British economic growth, tab. D.1, p. 566.

${ }^{58} \mathrm{~J}$. Gershuny, S. Jones, and P. Baert, 'The time economy or the economy of time', unpublished typescript (University of Oxford and University of Bath, 1991), ch. 8, opp. p. 12. In the US, men appear to have increased their working hours during the last decade: see Schor, Overworked American.
} 
total time available. A further 2 per cent was spent shopping. The vast bulk of the time available was spent outside the market, in various forms of social interaction, in domestic work, or alone. ${ }^{59}$

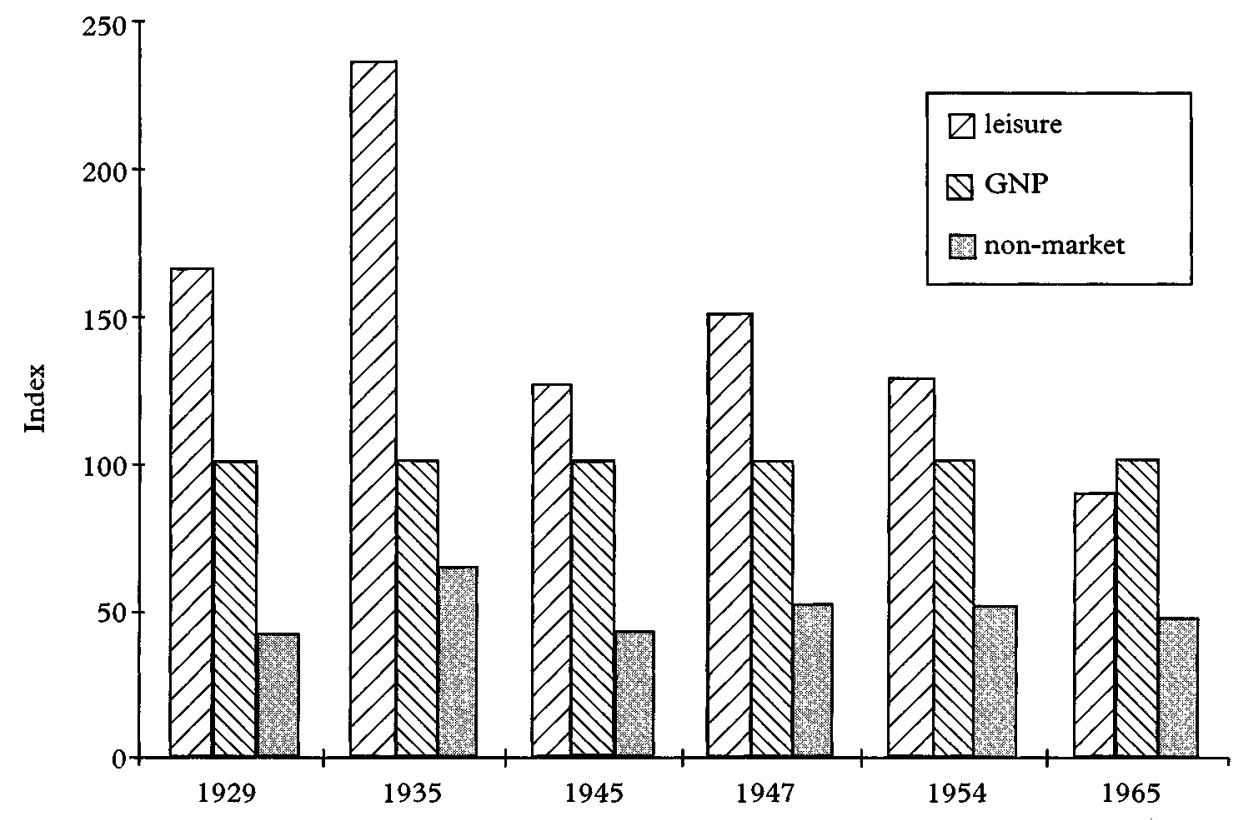

Figure 3. Leisure, GNP, and non-market activities, US, 1929-1965 Source: Nordhaus and Tobin, 'Is growth obsolete?', tab. A.17, p. 414

A massive asymmetry arises from the gift of life itself. Children are another good whose provision has shifted out of the market and into the gift economy. In pre-industrial and early industrial societies, children were able to bring in a current income, and were counted on for support in hardship, and in old age. The demographic transition is associated with children losing their economic value, and gaining a large affective value. They become economically worthless, but emotionally priceless. ${ }^{60}$ Child rearing can extend into three decades, and places heavy demands on mental energy and time. Attempts have been made to measure the money cost of children. The magnitudes are staggering. For Britain, the estimated cost in earnings forgone for an average woman with two children came to $£ 202,500$ in 1990 prices, approximately 46 per cent of her potential lifetime earnings. It was made up of earnings forgone while out of employment, while working shorter hours, and at lower rates of pay. ${ }^{61}$ The direct costs added another $£ 50,000$ or so. In the United States the earnings forgone appear to be much lower, but the direct costs much higher, as less time was taken off work, and more spent on

\footnotetext{
${ }^{59}$ Gershuny, Jones, and Baert, 'Time economy' (above, n. 58), tabs. 8.1 and $8.2: 28 \%$ for men, $14 \%$ for women.

${ }^{60}$ Zelizer, Pricing the priceless child, p. 209.

${ }^{61}$ Joshi, 'Cost of caring', p. 121.
} 
childcare. ${ }^{62}$ The capitalized rearing costs alone (excluding domestic labour) in the United States were estimated as representing 11 per cent of the total private capital stock in 1929 , and 6.5 per cent in $1969 .{ }^{63}$ The gift of life is only a modest addition to the macroeconomic measures of the household economy since most of it is already counted in household production. Parental care is an unmeasured but vital input into human capital, and determines the ability to participate in economy and society. When marriages break down, the probability of educational, behavioural, and emotional disorders is doubled, even after controlling for socioeconomic factors. ${ }^{64}$ This is not an argument against divorce, but an indication of the cost of inadequate parenting.

Another parental asymmetry arises from intergenerational transfers and bequests. From the point of view of the economic model of lifetime consumption (or 'permanent income'), bequests are an anomaly. Selfinterest ends at death. ${ }^{65}$ 'Strategic bequest' theory interprets the prospect of bequest as a form of bond, which is designed to elicit regard from offspring. ${ }^{66}$ One study estimated that bequests could account for between 15 and 70 per cent of net wealth in the United States; another estimates intended transfers as accounting for at least 20 per cent of net worth, and possibly much more; a third, using a different method, has found the range to be between 25 and 40 per cent in the US and Japan. ${ }^{67}$ Kotlikoff argues that all intergenerational transfers taken together (beyond the age of 18), including parental payments for higher education, account for about 80 per cent of assets in the US. ${ }^{68}$ Likewise, a good deal of life insurance cover may be regarded as reciprocal or altruistic transfers. ${ }^{69}$

How do offspring reciprocate? Across the life course, parents and children engage in constant interaction. In return for care and attention, children provide parents with status, a sense of worth, and sheer pleasure. ${ }^{70}$ But several sociological studies have indicated that in North America, at least, intergenerational reciprocity is asymmetrical, and that offspring get more in financial, household, and emotional, aid than they return. ${ }^{71}$ At the macro level, this asymmetry may be seen as an instance of delayed or indirect reciprocity. It is estimated that 60 per cent of workers, and 70 per cent of the elderly in the world today still rely

\footnotetext{
${ }^{62}$ Idem, 'Cash opportunity costs of childbearing', p. 58.

${ }^{63}$ Kendrick, Total capital, tab. B-29, pp. 222-3.

${ }^{64}$ Zill, Morrison, and Coiro, 'Long-term effects of divorce on children'; McLanahan and Bumpass, 'Intergenerational consequences of family disruption'; Wallerstein, 'Long-term effect of divorce on children'.

${ }^{65}$ As e.g. in the lifetime consumption theory of Modigliani and Brumberg; see Kotlikoff, 'Intergenerational transfers and savings'.

${ }^{66}$ Bernheim, Shleifer, and Summers, 'Strategic bequest motive'.

${ }^{67}$ Kotlikoff and Summers, 'Role of intergenerational transfers'; Barthold and Ito, 'Bequest taxes and accumulation of household wealth'.

${ }^{68}$ Kotlikoff, 'Intergenerational transfers and savings'.

${ }^{69}$ Zelizer, Morals and markets; Bernheim, 'How strong are bequest motives?'; Rossi and Rossi, Of human bonding, ch. 10.

${ }^{70}$ Rossi and Rossi, Of human bonding. In the words of R. Abrams, personal communication.

${ }^{71}$ Kulis, 'Social class and the locus of reciprocity'; Osborn and Williams, 'Determining patterns of exchanges'; Spitze and Logan, 'Helping as a component of parent-adult child relations'. Caplow, 'Rule enforcement without visible means', p. 1316.
} 
exclusively on family support for social security. ${ }^{72}$ In advanced societies, money transfers from the young to the old dwindle almost to nothing, which is remarkable in view of the large investments of the old in the young. ${ }^{73}$

But offspring and kin nevertheless reciprocate on a massive scale, not directly in money, but by caring for the old, the infirm, and the disabled. In the United States, about two-thirds of households maintain some form of reciprocal intergenerational assistance. ${ }^{74}$ In Britain in 1985, about one adult in seven (some 6 million people) was providing unpaid care, and about one in five households contained a carer. About 3 per cent of British adults (1.4 million) devoted at least 20 hours per week to caring and 8 per cent carried the main responsibility for looking after someone. ${ }^{75}$ Obligations arose, and were discharged, in a complex web of personal reciprocity, in which intensity of kinship was only one factor, and less important than the quality of previous interactions. ${ }^{76}$ Indeed, caring extended well beyond the family circle: about 28 per cent of those cared for were friends or neighbours. ${ }^{77}$ Based on local authority pay rates (of $£ 7$ per hour in 1989), the market value of caring provided by unpaid carers came to $£ 39.1$ billion in 1992 , or about 7.5 per cent of national income in that year. Of the time that this represents, 83 per cent was spent on caring for the aged. ${ }^{78}$ In total, this was almost four times as much as joint private and public expenditure for long-term care, and about the same as the total spent on the National Health Service. ${ }^{79}$

\section{III}

Discretion at work involves an element of gifting. When intensity and quality of effort are difficult to observe, they are to that extent discretionary, and need to be acknowledged reciprocally.

In managing their industrial relations, American executives have oscillated between two approaches, 'hard' and 'soft'. To achieve scale economies with poorly educated immigrants, they turned to strict discipline and time management, attempting to isolate the worker and to depersonalize the working environment. Application fell short of the ideal even in Detroit, ${ }^{80}$ and proved impossible to implement fully in more cohesive environments, such as Britain and Japan. An alternative tradition has advocated the carrot of regard, from the paternalism of the late Victorian period, to the 'human potential' approach of the 1920 s and leading up

\footnotetext{
${ }^{72}$ World Bank, Averting the old age crisis, p. 49.

${ }^{73}$ Ibid. tab. 2.3, p. 63.

${ }^{74} \mathrm{Kulis}$, 'Social class and the locus of reciprocity', figs. 1-2, pp. 489-90.

${ }^{75}$ Green, 'Informal carers', p. 1.

${ }^{76}$ Finch and Mason, Negotiating family responsibilities; Twigg, Carers; Finch, 'Responsibilities and the quality of relationships in families'; Rossi and Rossi, Of human bonding.

${ }^{77}$ Ibid., tab. 2.3, p. 8 .

${ }^{78}$ Laing, Financing long-term care, tab. 3, p. 39.

${ }^{79}$ Ibid.; Great Britain, Department of Health, Health and personal social services statistics for England, 1994 edn., tab. 7.2, p. 111 (data for England, extrapolated to the UK).

${ }^{80}$ Mathewson, Restriction of output among unorganized workers.
} 
to recent doctrines, in which management gurus have preached 'empowerment' in the workplace. ${ }^{81}$ Even the largest multinational corporation and the largest factory are made up of small groups, in the paintshop, on the assembly line, or in the boardroom. In face-to-face settings, the economy of regard kicks in. It has long been a powerful element in the solidarity culture of restricted effort in Britain. In the last two decades, it is increasingly being harnessed in the service of productivity: starting with 'quality circles', and moving on to the latest buzzword, 'team production' ${ }^{82}$ In Japanese industrial culture, it is underpinned by a gift economy of secure employment and overt rituals of mutual obligation between worker and corporation. ${ }^{83}$

From a different perspective, the 'New Institutional Economics' accepts that contractual obligations are difficult to specify completely in advance. ${ }^{84}$ One implication (rejected, however, by Williamson) is that they rely on reciprocal goodwill for their application. Keynesian economists have applied the idea to labour markets: Akerlof has explained the persistence of wages above market clearing levels as evidence of implicit contracts, of a gift relation between employers and workers. Where effort and quality are difficult to monitor, workers give effort and commitment voluntarily in return for levels of pay and regard that exceed market clearing levels. ${ }^{85}$ Effort is difficult to monitor, and Holmstrom and Milgrom detect elements of discretionary gift economy in any fixed wage. ${ }^{86}$

In the professional sphere, academic tenure was once a gift of lifetime income, usually by a group of peers, subject only to minimal contractual obligations. The recipient had discretion to repay the gift in the time and quality of his choosing. Some may have failed to honour the deal. What kept the others honest were the bonds of regard. There was little systematic monitoring, but the professor was under scrutiny from his immediate colleagues, and also in the 'invisible college' of far-flung peers, where reputations were made and maintained. Another form of obligation may arise between teacher and students; indeed, the conflicting demands of these two bonds are often difficult to resolve. Analogous regard incentives are to be found in most professions. ${ }^{87}$

\section{IV}

Farming remains an extension of the household form of production. In the long term, it has largely resisted the economies of scale offered by the labour market. Premodern agriculture often used communal forms of management. After the transition to capitalism, agriculture continues, in the most advanced countries, to be dominated by family farms, with a

\footnotetext{
${ }^{81}$ Waring, Taylorism transformed.

${ }^{82}$ e.g. Gmelch and Miskin, Productivity teams; Wellins et al., Empowered teams.

${ }^{83}$ e.g. Hampden-Turner and Tompenaars, Seven cultures of capitalism, ch. 8 .

${ }^{84}$ Williamson, Economic institutions of capitalism.

${ }^{85}$ Akerlof, 'Labor contracts as partial gift exchange'.

${ }^{86}$ Holmstrom and Milgrom, 'Multitask principal-agent analyses'.

${ }^{87}$ These are not discussed here for lack of space.
} 
little hired help. ${ }^{88}$ In the United States, the percentage of farms operated by their owners was 87 in 1970, and family farming dominates agriculture in North America up to the present. ${ }^{89}$ Individual farm acreage has increased with better technology, and the number of farms and farmers has declined, but farmwork is still largely a family (or very small business) affair: the ratio of self-employed and family to paid workers in US agriculture was 2.7 in 1960 , and still 1.8 in $1985 . .^{\circ}$

Except for the seasonal peaks, there are few economies of scale for labour in agriculture. On the family farm the face-to-face methods of household work allocation are used for market production. The typical hired hand in North American family farming was also a boarder. The earlier trend towards large farms, which developed in European agriculture during the high-farming/high prices period up to 1870 , was reversed during the subsequent quarter-century of depression, when farmers found it more difficult to bid in the labour market, and drew increasingly on family labour. ${ }^{91}$ From the 1870 s to the 1890 s, family farmers in North America, Germany, France, Scandinavia, and the Low Countries had to cope with falling prices. In many countries, they turned to cooperation. On their farmsteads, they applied the incentives of regard, increasingly reverting to family labour (one should not idealize these bonds, which often weighed heavily on wives and offspring). In staying on the farm, they sacrificed income for dignity. Their product, however, had to be sold for cash in impersonal markets. ${ }^{92}$ As Hofstadter argues, that is what accounts for the particular moral vehemence of agrarian pressure groups, their conviction of virtue, their sense of outrage and wrong. ${ }^{93}$ Agrarians laid moral claims on the rest of society which continued to resonate even after the agrarian upturn. ${ }^{94}$ They are exemplified in the persistence of the Common Agricultural Policy in Europe and farm support programmes in North America, despite their familiar abuses..$^{95}$ The Israeli government recently agreed to underwrite a massive financial bail-out of cooperative agriculture, for similar reasons.

We have seen that gifting needs to ascertain preferences from the outside. That is also the basic problem of selling. There is an overlap between the two forms of exchange, and regard pervades the market.

Some goods are useful only or mainly as gifts. Greeting cards are one example, gift wrappers, toys, flowers, and wedding rings are others. Davis

\footnotetext{
${ }^{88}$ Offer, Agrarian interpretation, pp. 110-6; Allen, D. W. and Leuck, D., 'The nature of the farm', unpublished paper (Simon Fraser University, Burnaby, B.C., and North Carolina State University, Raleigh, N.C., 1995).

${ }^{89}$ Allen and Leuck, ibid., pp. 3-5.

${ }^{90}$ US Bureau of Census, Statistical abstract 1989, tab. no. 1075, p. 626.

${ }^{91}$ Koning, Failure of agrarian capitalism.

${ }^{92}$ Ibid.; Offer, Agrarian interpretation, ch. 8.

${ }_{93}$ Hofstadter, Age of reform, pp. 46-7.

94 Offer, Agrarian interpretation, ch. 11, esp. pp. 151-2; pp. 381-2.

${ }^{95}$ Koning, Failure of agrarian capitalism.
} 
has estimated the scale of all retail purchases for gift giving at approximately 4.3 per cent of consumer expenditure in Britain in 1968.96 The year and the life cycle are punctuated by gifting occasions, by birthdays, weddings, and holidays. Durable retailing has a large peak at Christmas. In 1990, US households spent an average of $\$ 770$ on Christmas purchases, $\$ 72$ billion altogether, about 1.9 per cent of total consumer expenditure. ${ }^{97}$ In 'Middletown' in 1978, 39.5 Christmas gifts were inventoried for each respondent, and the celebrations accounted for about 4 per cent of total annual expenditures. ${ }^{98}$

Advertising attempts to apply mass production to personal suasion. Marketers strive to endow their goods with a 'personality', by means of branding. An advertisement can simulate a smile and reproduce it by the million. US magazine advertising between the $1940 \mathrm{~s}$ and the $1960 \mathrm{~s}$ usually incorporated an element of direct interpersonal appeal, in the form of 'endorsement' which was ubiquitous in that period in various forms. Price information was almost never included. This simulated regard was designed to bypass the filter of reason, in order to stimulate an obligation to purchase in the customer's mind. ${ }^{99}$ Tupperware, Avon, and Ann Summers recruit women to draw on their social networks and convene house parties, where the conventions of female reciprocity are invoked to sell plastic tableware, cosmetics, or sexual accessories. In the last two decades marketing has increasingly aimed to escape 'the law of one price', to discriminate among different market segments, in order to push prices up the demand curve. ${ }^{100}$ As information becomes cheaper, marketers attempt to personalize their appeal, and to collect information about individual clients in so-called 'database marketing'. The goal is to target promotions at the smallest possible market niche-the individualin order to simulate a personal relationship between sellers and buyers. Customers are increasingly exposed to personalized birthday letters and sales pitches cunningly disguised as personal communications. ${ }^{101}$

Advertising has accounted for 2 to 3 per cent of GDP in the United States since the $1920 \mathrm{~s}$. But this kind of simulated intimacy, however vivid, is no substitute for interpersonal persuasion. When selling at fixed prices to anonymous consumers, advertising is chosen. When selling high value goods to individuals, personal bonding is preferred. Table $1 \mathrm{com}-$ pares advertising and personal selling costs for department stores, wholesalers, and manufacturers in the United States in the 1930s. Even at the retail level, outlays on personal selling were almost double those on advertising. At the wholesale and producer goods level, selling costs remained high, but the vast bulk of the marketing effort was devoted to personal selling, in face-to-face interactions (column 4).

\footnotetext{
${ }^{96}$ Davis, 'Gifts and the UK economy', pp. 412-3.

${ }^{97}$ Solow, 'Is it really the thought that counts?', pp. 506-7.

${ }^{98}$ Caplow, 'Rule enforcement without visible means', p. 1307; see also Miller, Unwrapping Christmas.

${ }^{99}$ Offer, 'Mask of intimacy'.

${ }^{100}$ Gunter and Furnham, Consumer profiles.

101 'Databàse marketing', Bus. Week, 5 Sept. 1994, p. 56; personal experience.
} 
Table 1. Advertising and personal selling costs in retail, wholesale, and manufacturing, US, 1930s

\begin{tabular}{|c|c|c|c|c|c|c|}
\hline & \multicolumn{3}{|c|}{ Mean percentage of sales } & \multirow[b]{2}{*}{$\begin{array}{l}\text { Mean personal } \\
\text { selling/advertising } \\
\text { ratio }\end{array}$} & \multirow[b]{2}{*}{$\begin{array}{l}\text { Number of } \\
\text { observations }\end{array}$} & \multirow[b]{2}{*}{ Year } \\
\hline & $\begin{array}{l}\text { Advertising } \\
\text { and sales } \\
\text { promotion }\end{array}$ & $\begin{array}{c}\text { Personal } \\
\text { selling }\end{array}$ & $\begin{array}{c}\text { Total } \\
\text { marketing } \\
\text { expenditure }\end{array}$ & & & \\
\hline Retail & & & & & & \\
\hline Dept. stores (sizes) & 4.6 & 9.3 & 13.9 & 2.1 & 9 & 1935 \\
\hline \multicolumn{7}{|l|}{$\begin{array}{l}\text { Wholesale } \\
\text { (sectors) }\end{array}$} \\
\hline Profitable & 1.5 & 6.9 & 8.4 & 16.2 & 32 & 1934 \\
\hline Unprofitable & 0.8 & 8.6 & 9.4 & 21.6 & 32 & 1934 \\
\hline \multicolumn{7}{|l|}{$\begin{array}{l}\text { Manufacturing } \\
\text { (industries) }\end{array}$} \\
\hline Consumer goods & 5.8 & 11.4 & 17.2 & 2.6 & 19 & 1931 \\
\hline Producer goods & 2.3 & 10.1 & 12.4 & 5.1 & 10 & 1931 \\
\hline
\end{tabular}

Note: Means of data columns

Source: Borden, Economic effects of advertising, tabs. 6, 7, 8, pp. 63, 65, 67

The common perception is that retail customers are open to manipulation, while business to business trading is pure calculation. It appears, however, that inter-business trading involves a massive effort of interpersonal persuasion. Department stores and consumer goods manufacturers spent more than twice as much on personal selling as on advertising. Producer goods manufacturers spent a little less on sales overall, but devoted about five times as much to personal selling as to advertising. ${ }^{102}$

Any difference in quality, delivery, service, and so on, can be offset by competitive prices, which theory says will be shaved of all profit. Hence the only remaining source of market advantage could well be the quality of regard. The impression that personal interaction was vital to business is reinforced by the finding that almost half of US GNP in 1970 could be described as transaction costs, i.e. as the measured extent of the divergence from the ideal of costless transactions. Of this, 55 per cent was incurred between firms. ${ }^{103}$ The proportion of sales workers in the US labour force rose from 4 per cent in 1900 to 7.5 per cent in 1970, while in Britain it was higher still, 9.5 per cent in 1961, though it dropped to 8.8 per cent in $1981 .^{104}$ On this measure as well, the impersonal market has (until recently) retreated, not expanded.

Bonding for sales purposes is known as 'relationship selling'. ${ }^{105} \mathrm{~A}$ stockbroker explains in a company instructional video, 'I could be the best stock-picker in the world, but if I don't establish a relationship, the

\footnotetext{
1021931 , however, was not a normal year.

${ }^{103}$ Wallis and North, 'Should transaction costs be subtracted from gross national product?', pp. 651-4.

${ }^{104}$ Wallis and North, 'Measuring the transaction sector', tab. 3.1, p. 106; Mitchell, British historical statistics, tab. 'Labour force 2', p. 107; Great Britain, Census 1981, tab. 12, p. 52.

${ }^{105}$ Levitt, Marketing imagination, ch. 6.
} 
client won't stick with me. ${ }^{106}$ A year-long participant-observer of a Xerox sales office in Cleveland, Ohio in the 1990s describes how intensely corporations rely on bonding to capture and hold their business customers, as several quotations will illustrate:

It's a friendship. The more routine the business becomes, the less it threatens the friendship, and the more solid the friendship, the more Diane can expect business as a matter of routine. ${ }^{107}$

It's a saleman's favorite tone, a way of establishing a sense of almost illicit familiarity, a way of making the listener feel privileged and special. ${ }^{108}$

A salesman needs nothing less than to be loved by everyone, so he's haunted by the specter of failure as a personal rejection, a sort of unrequited love. ${ }^{109}$

Sales was pressing the flesh. The act of trust, of partnership, of friendly congress. ${ }^{110}$

No one was immune to affection, calculated or otherwise. ${ }^{111}$

The toughest customers would ask for more information until they got it ... but most customers wanted to preserve their friendly relationship with the salesman.... They valued the relationship as much as they valued the particulars of a given deal. ${ }^{112}$

The standard negotiating fixture in commerce is the 'business lunch', which uses the gift-exchange trappings of food and hospitality to create an emotional setting for trade. That part of the hospitality industry which does not cater primarily to courtship, kinship, or friendship, relies on the businessman, travelling in pursuit of the personal contact.

Personal obligation can drive consumer preferences. In 1965, of US car buyers giving the prime reason for choosing a particular dealer, 11.9 per cent of new-car owners cited 'personal relationship'; for used-car owners the level was higher at 12.7-15.2 per cent, and another 5 per cent cited positive dealer attitude or reputation. Earlier surveys found comparable results. ${ }^{113}$

The mix of regard and of salesmanship is uneasy. Many employees, like the Xerox salespeople, have found fulfilment in genuine exchanges of regard, using time and goods provided by their employer. But because money is involved, authenticity is suspect-it is pseudo regard. Rapport with customers is often driven, back at the office, by output quotas as relentless as any in the old Soviet Union (with similar techniques of emotional terror and account massaging). ${ }^{114}$ In the web of commerce, every human bond is open to betrayal. That, at any rate, is the theme

106 Shorris, Nation of salesmen, p. 308.

${ }^{107}$ Dorsey, Force, p. 45.

108 Ibid., p. 92.

109 Ibid., p. 179.

110 Ibid., p. 204.

111 Ibid, p. 121.

112 Ibid., p. 204.

${ }^{113}$ Look, National automobile and tire survey, 1965, pp. 31,43; ibid., 1958, p. 36; United States, Automobile price labeling, hearings, pp. 56-60.

${ }^{114}$ Ibid,, passim.

(ㄷ) Economic History Society 1997 
of a vein of critical writing, from Arthur Miller's Death of a salesman, Saul Bellow's Seize the day, and David Mamet's Glengarry Glen Ross, to such documentaries as Dorsey's The force, and a recent cover story in Business Week. ${ }^{115}$

\section{VI}

If entrepreneurship could be taught, many more would succeed. It begins with an untried concept, and depends on the ability to inspire trust: to attract reciprocal transfers from investors, lenders, suppliers, and customers. ${ }^{116}$ It is often those entrepreneurs who understand the gift economy who are most likely to succeed in the market economy. But success may also require the ruthless ability to disown the obligations of regard. ${ }^{117}$ The same applies to the practice of politics: a field too vast to more than mention here.

A common identity can substitute for face-to-face relations. Jewish Maghribi traders in the eleventh-century Mediterranean had enough in common to establish a high probability of trustworthiness: their communal culture made the penalty of exclusion exceptionally painful. ${ }^{118}$ Similar bonds have facilitated the formation of other trading and entrepreneurial communities: the Quakers in Britain, the Parsis in India, the overseas Chinese. ${ }^{119}$ The diamond trade in Israel, one of its three world centres, relies on informal handshake contracts, sealed by the blessing 'Mazal Ubracha' (luck and bounty), and is dominated by Orthodox Jews. Business credit is essentially a form of delayed reciprocity. In its first century, British industrialization relied primarily on funds raised locally from family, friends, and business contacts, who based their trust on personal knowledge. ${ }^{120}$ The family firm and the partnership were typical forms of ownership. They remained so until the scale of economic projects (such as the railways and overseas enterprises) exceeded the resources of personal networks.

Asian entrepreneurs, especially the overseas Chinese, make extensive use of family and gift reciprocity. Chinese culture subscribes to guanxi, a set of norms of reciprocity and gifting, which promote trust among initiates and exclude others. In the People's Republic guanxi was necessary to obtain goods and services. Overseas Chinese had the cultural equipment to connect into these pre-existing webs, often by going back to their village or town of origin, and taking on a local partner. In the absence of secure property rights in the People's Republic, reciprocity

\footnotetext{
${ }^{115}$ Miller, Death of a salesman; Bellow, Seize the day; Mamet, Glengarry Glen Ross; Dorsey, Force; Maremont, 'Blind ambition'.

${ }^{116}$ Starr and MacMillan, 'Entrepreneurship, resource co-optation and social contracting'.

117 Choi, Paradigms and conventions, ch. 7.

${ }^{118}$ Greif, 'Reputation and coalitions'.

${ }^{119}$ Landa, Trust, ethnicity, and identity, chs. 5-6.

${ }^{120}$ Neal, 'Finance of business', pp. 152, 155; McCloskey, ‘1780-1860: a survey', p. 270.
} 
fulfils a similar function of making trade and investment possible. ${ }^{121}$ Hence, more than two-thirds of China's massive exports to the United States are routed through Hong Kong. ${ }^{122}$

\section{VII}

Loyalty and reciprocity can be used effectively for anti-social ends. Italy has its Cosa Nostra, the Chinese their Triads. A Russian Mafia, with deep roots in the past, is in the process of re-emerging. ${ }^{123}$ Small groups collude more effectively than large ones. ${ }^{124}$ Reciprocal communities of businessmen, professionals, and workers often organize for rent seeking. A strong gift economy can crowd out the market if exchange depends entirely on reciprocal inclusion. ${ }^{125}$ This is a strong argument for liberalism, for the impersonality of the market, the law, the public service, and the vote. Some forms of gifting are used to subvert the 'rules of the game'. Even law-abiding societies, with a tradition of public integrity, are not immune to 'old boy networks'. Illegal gift economies subvert the effectiveness of government, sometimes due to a general ethos of reciprocity (known as protektsia in eastern Europe and Israel), or the activities of organized crime. But corruption can also be beneficial. Like the market economy, the planned economy in eastern Europe also depended on an extensive network of 'fixers', who acted as brokers in a gift economy (blat) mediated by their access to resources, relationships and reputations. ${ }^{126}$

\section{VIII}

The foregoing accounts of reciprocal exchange lead to figure 4, which explores the interaction and the boundaries of the gift and the market economies. It is meant entirely as an heuristic device. It abstracts, for this purpose, from the public sector mode of redistribution. That may be conceived of as yet another system of exchange, extending to the left. The horizontal axis $O Q$ measures the output of a good (or of 'all goods') produced either (in the gift economy) 'with regard', or in the market economy, 'without regard'. The figure has two demand and supply scissors. The first (broken lines), is the gift system of exchange (analogous to figure 1), in which the terms of trade determine an approximate 'gift price'. In this system, goods are provided 'with regard'. Both supply and demand are price inelastic, in comparison with market production. In the case of supply, this rigidity arises from the limited capacity of time

\footnotetext{
${ }^{121}$ Hwang, 'Face and favor'; Smart and Smart, 'Personal relations and divergent economies'; Smart, 'Gifts, bribes and guanxi'; Yang, 'Gift economy and state power in China'; also Landa, Trust, ethnicity, and identity, ch. 5.

122 'China: the numbers game', The Economist, 14 Oct. 1995, p. 96.

${ }^{123}$ Booth, Triads; Murray and Baoqi, Origins of Tianduhi; Varese, 'Is Sicily the future of Russia?'; F. Varese, 'The ancestors', unpublished paper, Nuffield College, Oxford (1995).

${ }^{124}$ Olson, Rise and decline of nations.

${ }^{125}$ R. Kranton, 'Reciprocal exchange: a self-sustaining system', unpublished paper (University of Maryland, College Park, Md., 1995).

${ }^{126}$ Grossman, "Second economy" of the USSR'; idem, "Shadow economy" of the USSR'. 
and psychic energy. The demand curve mirrors this constraint, and its slope reflects the psychic costs of receiving gifts. To the right, market provision, 'without regard' is relatively more elastic to price, and so is demand.

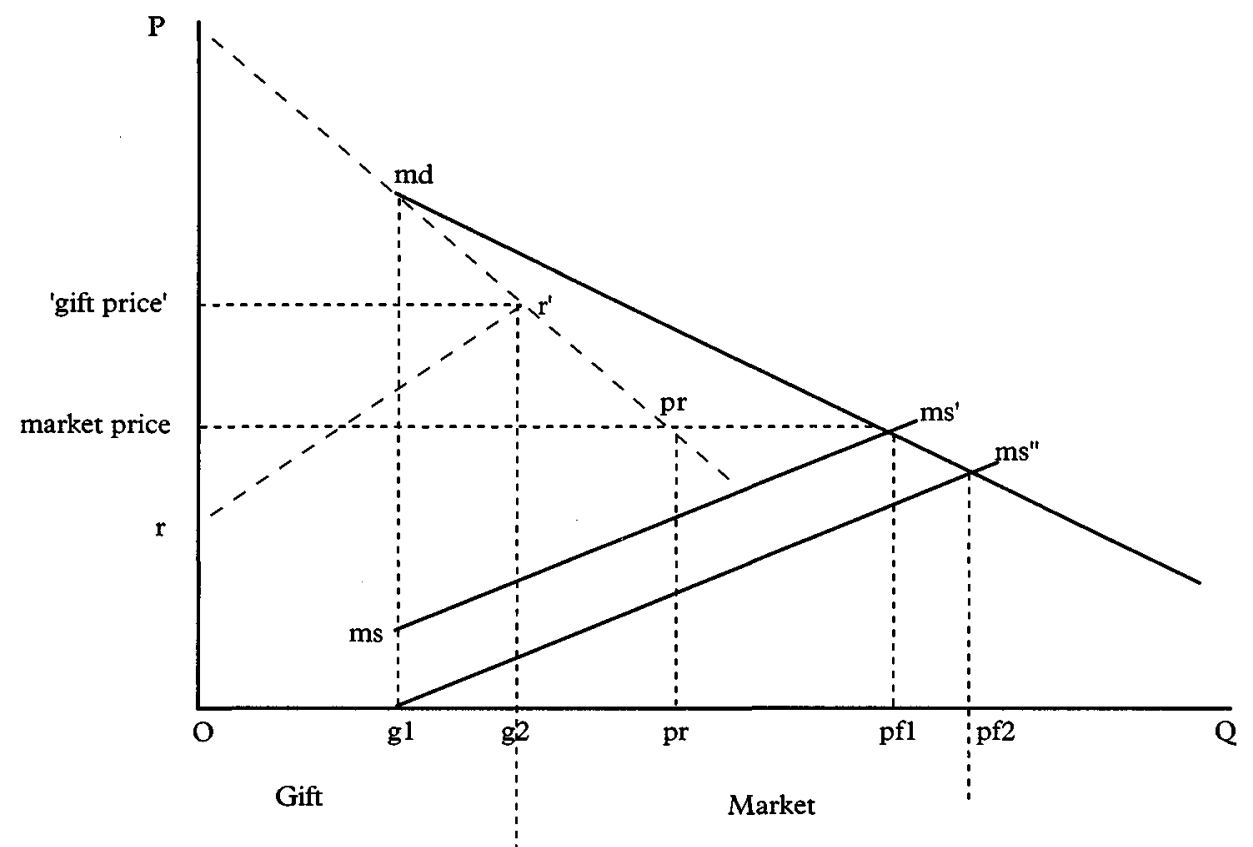

Figure 4. Boundaries of the gift and the market

Note: $\mathrm{P}$-pr $=$ regard demand curve

$\mathrm{rr}^{\prime}=$ regard supply curve (marginal cost)

md-ms" = market demand curve

ms-ms' = market supply curve (marginal cost)

$\mathrm{r}^{\prime}-\mathrm{pr}=$ pseudo-regard premium

$\mathrm{g} 2=$ boundary of the gift and the market

pf1 $=$ production frontier 1

pf2 $=$ production frontier 2 (after outward market supply shift g1-ms")

Horizontally along $O-g 1$, to the right of the origin, are goods that only the gift economy can supply, like 'the gift of life' or romantic love. The vertical $g 1-m d$ represents the boundary of the market: $m d-m s^{\prime \prime}$ is the market demand curve. Between $g 1$ and $g 2$, there is an overlap between the market supply curve $\left(m s-m s^{\prime}\right)$ and the regard curve: some goods (such as insurance) can be provided with or without regard. $O-g 2$ represents the extent of the authentic gift economy, and $g 2$ is the boundary between the gift and the market economy. Beyond $g 2$ is an area where the gift demand curve slopes downwards towards the equilibrium market price $\left(r^{\prime}-p r\right)$. This demand is beyond the capacity of gifting to satisfy, but it provides an opportunity for salesmanship, making use of pseudo-regard for price discrimination. $p f 1$ is the production frontier of the market economy.

The market marginal cost curve $\left(m s-m s^{\prime}\right)$ is more elastic than the gift economy supply curve. When market productivity increases the supply 
curve shifts outwards to $g 1-m s^{\prime \prime}$, and the relative share of the market will expand outwards to $p f 2$. This, in general, corresponds with the historical 'great transformation' from pre-industrial societies to those which are more market oriented. A more recent instance is the growth of the welfare state, where social insurance has shifted outwards from regardintensive family and community obligations, to mutual societies which still require an investment of regard, and finally to impersonal tax systems and insurance markets.

It is, however, possible for the regard curve to shift outwards as well, in consequence of technological change. Transport development has facilitated migrant remittance transfers. Telecommunications has extended the reach of both families and entrepreneurs. The shift from Taylorism to teams in the workplace, assisted by cheap computing power, has reinstated artisans in corporate factories. The slopes of the regard curve and the market supply curve are governed by their respective technologies. The relative shares of the gift and market exchange are determined dynamically over time by the cost of communication relative to the cost of time, i.e. by the growth of productivity in regard and in the market forms of exchange.

\section{IX}

The economy of regard operates wherever incentives are affected by personal relations. Its core is in the household, but it extends whenever people work in small groups or negotiate face to face. Gift exchange is sensitive to the cost of information and the cost of time. As market incomes rise, so does the cost of time. On the other hand, the cost of information is declining. These trends work in opposite directions. As the cost of time increases, regard-intensive exchanges such as childcare become more expensive. Men, for a long time, have traded working hours for more time at home, with the exception of workers in the higher professional and managerial occupations, who have sought regard in the workplace. This choice was even starker for women, and those who have had the most challenging careers have forgone children and often marriage as well. ${ }^{127}$ For women, market work provides additional choice and a new measure of regard. But the redirection of regard (by both men and women) is also creating a wake of social consequences, ranging from marriage breakdown at the personal end, to the fiscal crisis of the welfare state at the societal one.

Regard is difficult to measure because the yardstick of price is explicitly rejected. When regard and goods are traded together, 'revealed preferences' will therefore not measure accurately the welfare produced. It is consequently necessary to look for other indicators, to decipher the cues and language of regard. Otherwise, when making policy, there is an inclination to maximize only what is measurable, thus falling short of optimality. ${ }^{128}$ This failure is a feature of public policy: individuals are

${ }^{127}$ Joshi, 'Combining employment with childrearing'.

${ }^{128}$ Holmstrom and Milgrom, 'Multitask principal-agent analysis'. 
less likely to succumb in their private affairs, since regard is a compelling part of their preferences. In public services, there has been a strong movement towards simulated market forms of provision. In neglecting the economy of regard, these policies may fall well short of their objectives, because first, quantitative measures are often unable to capture quality, which is more easily monitored in face-to-face interaction with peers and clients; second, quantitative sanctions replace approbation with fear, and informal monitoring with costly evaluation, and lead to neglect of unmeasured but vital tasks; and third, there are unmeasured losses of regard, goodwill, and trust. Regard is a good in its own right, quite apart from its instrumental value, especially where personal interaction dominates exchange, as in education and medical care.

In the market sector, transactions legitimized by market impartiality, and justified as market-clearing, may actually be driven by pseudo-regard. One suspect is the rise of executive pay in the United States and Britain, which has reached such multiples of average earnings that it has alarmed even Business Week. Remuneration bears little relation to economic performance, and is influenced by the reciprocal gifting motives of compensation committee members. ${ }^{129}$

Decades after integration into the market economy, the kula and the potlatch have persisted in the South Seas and in the Pacific Northwest, absorbing ever larger resources in line with increased affluence. ${ }^{130}$ Likewise, a variety of reciprocal exchanges persist into the modern world. This peculiar form of exchange, with its personalized gift and discretionary delay, is required to authenticate regard. It motivates gains from trade in ways that are similar to the market. It persists because regard is an abiding need, perhaps 'wired in', which impersonal markets are poorly equipped to gratify.

\section{Nuffield College, Oxford}

\footnotetext{
${ }^{129}$ Byrne, Bongiorno, and Grover, 'That eye-popping executive pay'; 'Executive pay: the party ain't over yet', Business Week, 26 April 1993, pp. 56-79; Byrne, Foust, and Therrien, 'Executive pay'; Crystal, In search of excess.

${ }^{130}$ Gregory, 'Gifts', p. 527.
}

\section{Footnote references}

Akerlof, G., 'Labor contracts as partial gift exchange', Qu. F. Econ., 87 (1982), pp. 543-69.

Altman, I., 'Reciprocity of interpersonal exchange', $\not$. Theory Soc. Behaviour, 3 (1973), pp. 249-61. Anderson, B. L. and Latham, A. J. H., eds., The market in history (1986).

Argyle, M., 'Subjective well-being', in A. Offer, ed., In pursuit of the quality of life (Oxford, 1996), pp. 18-45.

Axelrod, R., The evolution of co-operation (New York, 1984).

Barthold, T. A. and Ito, T., 'Bequest taxes and accumulation of household wealth: US-Japan comparison', NBER Working Paper no. 3,692 (Washington, D.C., 1991).

Belk, R. W. and Coon, G. S., 'Can't buy me love: dating, money and gifts', Advances in Consumer Res., 18 (1991), pp. 521-7.

Bellow, S., Seize the day (1957).

Bellow, S., 'The old system', in idem, Mosby's memoirs and other stories (Harmondsworth, 1971), pp. 45-81.

Ben-Porath, Y., 'The F-connection: families, friends, and firms and the organization of exchange', Pop. \& Dev. Rev., 6 (1980), pp. 1-30. 
Bernheim, B. D., 'How strong are bequest motives? Evidence based on estimates of the demand for life insurance and annuities', F. Pol. Econ., 99 (1991), pp. 899-927.

Bernheim, B. D., Shleifer, A., and Summers, L. H., 'The strategic bequest motive', $\mathcal{F}$. Pol. Econ., 93 (1985), pp. 1045-76.

Booth, M., The triads: the Chinese criminal fraternity (1990).

Borden, N. H., The economic effects of advertising (Chicago, 1942).

du Boulay, J., 'Strangers and gifts: hostility and hospitality in rural Greece', f. Med. Stud., 1 (1991), pp. 37-53.

Bourdieu, P., 'Les modes de domination', Actes de la recherche en sciences sociales, 2 (1976), pp. 122-32.

Brown, D. E., Human universals (New York, 1991).

Burgoyne, C. B. and Roth, D. A., 'Constraints on the use of money as a gift at Christmas: the role of status and intimacy', f. Econ. Psychol., 12 (1991), pp. 47-69.

Byrne, J. A., Bongiorno, L., and Grover, R., 'That eye-popping executive pay', Bus. Week, 25 April 1994, pp. 52-3.

Byrne, J. A., Foust, D., and Therrien, L., 'Executive pay: compensation at the top is out of control. Here's how to reform it', Bus. Week, 30 March 1992, pp. 52-8.

Cameron, S., 'The unacceptability of money as a gift and its status as a medium of exchange', $\mathfrak{F}$. Econ. Psychol., 10 (1989), pp. 253-5.

Caplow, T., 'Rule enforcement without visible means: Christmas gift giving in Middletown', Amer. F. Sociol., 89 (1984), pp. 1306-23.

Carrier, J. G., Gifts and commodities: exchange and westem capitalism since 1700 (1995).

Cashdan, E., ed., Risk and uncertainty in tribal and peasant economies (Boulder, Colo., 1990).

Choi, Y. B., Paradigms and conventions: uncertainty, decision making and entrepreneurship (Ann Arbor, 1993).

Collard, D., Altruism and economy (Oxford, 1978).

Cosmides, L. and Tooby, J., 'Cognitive adaptations for social exchange', in J. H. Barkow, L. Cosmides, and J. Tooby, eds., The adapted mind: evolutionary psychology and the generation of culture (New York, 1992), pp. 163-228.

Crystal, G. S., In search of excess: the overcompensation of American executives (New York, 1992).

Dahlman, C. J., The open fields system and beyond: a property rights analysis of an economic institution (Oxford, 1980).

Dasgupta, P., An inquiry into well-being and destitution (Oxford, 1993).

Davis, J., 'Gifts and the UK economy', Man, 7 (1972), pp. 408-29.

Dixit, V., 'Economics and sociology of bride-price and dowry in eastern Rajasthan', Internat. $\mathcal{F}$. Sociol. Law, 19 (1991), pp. 341-54.

Dorsey, D., The force (1994).

Dunbar, R., Grooming, gossip and the evolution of language (1996).

Eisner, R., The total incomes system of accounts (Chicago, 1989).

Ekman, P., Telling lies (New York, 1985).

Ekman, P., ed., Emotion in the human face, 2nd edn. (Cambridge, 1982).

Farber, B., 'Limiting reciprocity among relatives: theoretical implications of a serendipitous finding', Sociol. Perspectives, 32 (1989), pp. 307-30.

Finch, J., 'Responsibilities and the quality of relationships in families', in A. Offer, ed., In pursuit of the quality of life (Oxford, 1996), pp. 119-39.

Finch, J. and Mason, J., Negotiating family responsibilities (1993).

Finley, M., The ancient economy (1973).

Fiske, A. P., 'Relativity within Moose ("Mossi") culture: four incommensurable models for social relationships', Ethos, 18 (1990), pp. 180-204.

Frank, R. H., Passions within reason (New York, 1989).

Frank, R. H., Microeconomics and behavior (New York, 1991).

Gershuny, J., 'Are we running out of time?', Futures, 24 (1992), pp. 3-22.

Gershuny, J. and Halpin, B., 'Time use, quality of life, and process benefits', in A. Offer, ed., In pursuit of the quality of life (Oxford, 1996), pp. 188-210.

Gifford, S., 'The allocation of entrepreneurial attention', $\mathcal{~}$. Econ. Behavior $\mathcal{F}$ Organization, 19 (1992), pp. 265-84.

Gingrich, A., 'Is wa milh: Brot und Salz. Vom Gastmahl bei den Hawlan bin Amir im Jemen', Mitteilungen der Anthropologischen Gesellschaft in Wien, 116 (1986), pp. 41-69.

Gmelch, G. and Gmelch, S.-B., 'Begging in Dublin: the strategies of a marginal urban occupation', Urban Life, 6 (1978), pp. 439-54.

Gmelch, W. H. and Miskin, V. D., Productivity teams: beyond quality circles (New York, 1984).

Gonul, H., 'Is money an acceptable gift in Cyprus?', Perceptual $\mathcal{G}$ Motor Skills, 61 (1985), p. 1074.

Gottman, J. M. and Levenson, R., 'The social psychophysiology of marriage', in P. Noller and M. A. Fitzpatrick, eds., Perspectives on marital interaction (Clevedon, 1988). 
Green, H., Informal carers, General Household Survey 1985, series GN5, no. 15, supplement A (1988).

Gregory, C. A., Gifts and commodities (1982).

Gregory, C. A., 'Gifts', in M. Milgate et al., eds., The new Palgrave dictionary of economics (1987), pp. 524-8.

Greif, A., 'Reputation and coalitions in medieval trade: evidence on the Maghribi traders', 7 . Econ. Hist., XLIX (1989), pp. 857-82.

Grossman, G., 'The "second economy" of the USSR', Problems of Communism, 26 (1977), pp. 25-40.

Grossman, G., 'The "shadow economy" in the socialist sector of the USSR', in NATO Economics and Information Directorate, The CMEA five-year plans (1981-1985) in a new perspective (Brussels, 1982).

Gunter, B. and Furnham, A., Consumer profiles: an introduction to psychographics (1992).

Hampden-Turner, C. and Tompenaars, F., The seven cultures of capitalism (1994).

Hayek, F. A., 'The ise of knowledge in society', Amer. Econ. Rev., 35 (1945), pp. 519-30.

Hite, S., The Hite report: zomen gnd love: a cultural revolution in progress (1987).

Hochschild, A. R., The managed heart: commercialization of human feeling (Berkeley, Cal., 1983).

Hofstadter, R., The age of reform: from Bryan to F.D.R. (New York, 1955).

Holmstrom, B. and Milgrom, P., 'Multitask principal-agent analyses: incentive contracts, asset ownership, and job design', f. Law, Econ. E Organization, 7 (1991), special issue, pp. 24-52.

Humphries, S., A secret world of sex: forbidden fruit: the British experience 1900-1950 (1988).

Hwang, K., 'Face and favor: the Chinese power game', Amer. F. Sociol., 92 (1987), pp. 944-74.

Ironmonger, D., Households work (Sydney, 1989).

Jackson, T. and Marks, N., Measuring sustainable economic welfare: a pilot index, 1950-1990 (Stockholm, 1994).

Joshi, H., 'The cash opportunity costs of childbearing: an approach to estimation using British data', Pop. Stud., 44 (1990), pp. 41-60.

Joshi, H., 'The cost of caring', in C. Glendinning and J. Millar, eds., Women and poverty in Britain: the 1990s (1992), pp. 110-25.

Joshi, H., 'Combining employment with child-rearing: the story of British women's lives', in A. Offer, ed., In pursuit of the quality of life (Oxford, 1996), pp. 88-118.

Kelly, R. L., The foraging spectrum: diversity in hunter-gatherer lifeways (Washington, D.C., 1995).

Kendrick, J. W., The formation and stocks of total capital (New York, 1976).

Khare, R. S., 'Indian hospitality: some cultural values and social dynamics', Cultural heritage of the Indian village, British Museum Occasional Paper no. 47 (1991), pp. 45-61.

Komarovsky, M., Blue-collar marriage (New Haven, 1962).

Koning, N., The failure of agrarian capitalism: agrarian politics in the United Kingdom, Germany, the Netherlands and the USA, 1846-1919 (1994).

Kotlikoff, L. J., 'Intergenerational transfers and savings', f. Econ. Perspectives, 77 (1988), pp. 41-58.

Kotlikoff, L. J. and Spivak, A., 'The family as an incomplete annuities market', $\mathcal{F}$. Pol. Econ., 89 (1981), pp. 942-63.

Kotlikoff, L. J. and Summers, L. H., 'The role of intergenerational transfers in aggregate capital accumulation', f. Pol. Econ., 89 (1981), pp. 706-32.

Kreps, D. M., A course in microeconomic theory (New York, 1990).

Kulis, S. S., 'Social class and the locus of reciprocity in relationships with adult children', $f$. Fam. Issues, 13 (1992), pp. 482-504.

Laing, W., Financing long-term care: the crucial debate (1993).

Landa, J. T., Trust, ethnicity and identity: beyond the new institutional economics of ethnic trading networks, contract law, and gift-exchange (Ann Arbor, 1994).

Levitt, T., The marketing imagination (New York, 1983).

Lojkine, J., 'Valeur, valeur d'usage et valeur symbolique', Cahiers Internationaux de Sociologie, 38 (1991), pp. 25-48.

Look, National automobile and tire survey (Annual, New York, 1956-65).

Lucas, R. E. and Stark, O., 'Motivations to remit: evidence from Botswana', F. Pol. Econ., 93 (1985), pp. 901-18.

Malinowski, B., Argonauts of the western Pacific (New York, 1922).

Mamet, D., Glengarry Glen Ross (1990).

Maremont, M., 'Blind ambition: how the pursuit of results got out of hand at Bausch \& Lomb', Bus. Week, international edn, 23 (1995), pp. 46-56.

Matthews, R. C. O., Feinstein, C. H., and Odling-Smee, J. C., British economic growth, 1856-1973 (Oxford, 1982).

Mathewson, S. B., Restriction of output among unorganized workers (New York, 1931).

Mauss, M., The gift: the form and reason for exchange in archaic societies, trans. W. D. Halls (1990, first pub. 1925). 
McCloskey, D. N., '1780-1860: a survey', in R. Floud and D. N. McCloskey, eds., The economic history of Britain since 1799, 2nd edn., 1 (Cambridge, 1994), pp. 242-70.

McLanahan, S. and Bumpass, L., 'Intergenerational consequences of family disruption', Amer. $\mathcal{F}$. Sociol, 94 (1988), pp. 130-52.

McLean, I. and Poulton, J., 'Good blood, bad blood, and the market: the gift relationship revisited', F. Pub. Pol., 6 (1987), pp. 431-45.

Michael, R. T., Gagnon, J. H., Laumann, E. O., and Kolata, G., Sex in America: a definitive survey (1994).

Miller, A., Death of a salesman (1968).

Miller, D., ed., Unzurapping Christmas (Oxford, 1993).

Mitchell, B. R., British historical statistics (Cambridge, 1988).

Murray, D. H. with Baoqi, Q., The origins of the Tiandihui: the Chinese triads in legend and history (Stanford, 1994).

Neal, L., 'The finance of business during the industrial revolution', in R. Floud and D.N. McCloskey, eds., The economic history of Britain since 1799, 2nd edn., 1 (Cambridge, 1994), pp. 151-81.

Nordhaus, W. and Tobin, J., 'Is growth obsolete?', in J. Tobin, ed., Essays in economics: theory and policy (Cambridge, Mass., 1982), pp. 360-451.

Offer, A., The First World War: an agrarian interpretation (Oxford, 1989).

Offer, A., 'The mask of intimacy: advertising and the quality of life', in idem, ed., In pursuit of the quality of life (Oxford, 1996), pp. 211-55.

Olson, M., The rise and decline of nations: economic growth, stagflation and social rigidities (New Haven, 1982).

Osborn, R. W. and Williams, J. I., 'Determining patterns of exchanges and expanded family relationships', Internat. f. Sociol. Family, 6 (1976), pp. 197-209.

Ostrom, E., Gardner, R., and Walker, J., Rules, games and common-pool resources (Ann Arbor, 1994).

Parry, J., 'On the moral perils of exchange', in J. Parry and M. Bloch, eds., Money and the morality of exchange (Cambridge, 1989), pp. 64-93.

Peterson, N., 'Demand sharing: reciprocity and the pressure for generosity among foragers', Amer. Anthropologist, 95 (1993), pp. 860-74.

Pinker, S., The language instinct: the new science of language and mind (1994).

Pitt-Rivers, J., 'The stranger, the guest and the hostile host: introduction to the study of the laws of hospitality', in J. G. Peristiany, ed., Contributions to Mediterranean sociology (Paris, 1968), pp. 13-30.

Polanyi, K., The great transformation: the political and economic origins of our time (Boston, 1944).

Polanyi, K., 'The economy as instituted process', in G. Dalton, ed., Primitive, archaic and modern economies: essays of Karl Polanyi (Garden City, N.J., 1968), pp. 139-74.

Reynolds, S., Kingdoms and communities in western Europe, 900-1300 (Oxford, 1984).

Robertson, D. H., 'What does the economist economize?', in idem, Economic commentaries (1956), pp. 14-55.

Rose-Ackerman, S., 'Altruism, nonprofits, and economic theory', $\mathcal{F}$. Econ. Lit., 34 (1996), pp. 701-28.

Rossi, A.S. and Rossi, P. H., Of human bonding: parent-child relations across the life course (New York, 1990).

Roth, A. E., 'Bargaining experiments', in J. H. Kagel and A. E. Roth, eds., Handbook of experimental economics (Princeton, 1995), pp. 253-348.

Rubin, L. B., Worlds of pain: life in the working-class family (New York, 1976).

Rubin, Z., 'Lovers and other strangers: the development of intimacy in encounters and relationships', Amer. Scientist, 62 (1974), pp. 182-90.

Sahlins, M., Stone age economics (1974).

Schor, J. B., The overworked American: the unexpected decline of leisure (New York, 1991).

Shorris, E., $A$ nation of salesmen: the tyranny of the market and the subversion of culture (New York, 1994).

Simpson-Herbert, M., 'Women, food and hospitality in Iranian society', Canberra Anthropology, 10 (1987), pp. 24-34.

Smart, A., 'Gifts, bribes, and guanxi: a reconsideration of Bourdieu's social capital', Cult. Anthropology, 8 (1993), pp. 388-408.

Smart, J. and Smart, A., 'Personal relations and divergent economies: a case-study of Hong-Kong investment in South China', Internat. F. Urban \& Regional Res., 15 (1991), pp. 216-33.

Smith, A., The theory of moral sentiments, eds. D. D. Raphael and A. L. Macfie (Oxford, 1976).

Smith, E. A. and Boyd, R., 'Risk and reciprocity: hunter-gatherer socioecology and the problem of collective action', in E. Cashdan, ed., Risk and uncertainty in tribal and peasant economies (Boulder, Colo., 1990), pp. 167-91.

Snooks, G. D., Portrait of the family within the total economy: a study in longmun dynamics. Australia 1788-1990 (Cambridge, 1994). 
Solow, J. L., 'Is it really the thought that counts-toward a rational theory of Christmas', Rationality $\mathcal{E}$ Soc., 5 (1993), pp. 506-17.

Spitze, G. and Logan, J. R., 'Helping as a component of parent-adult child relations', Research on Aging, 14 (1992), pp. 291-312.

Stark, O., Altruism and beyond: an economic analysis of transfers and exchanges within families and groups (Cambridge, 1995).

Starr, J. and MacMillan, I. C., 'Entrepreneurship, resource co-optation, and social contracting', in A. Etzioni and P. R. Lawrence, eds., Socio-economics: towards a new synthesis (Armonk, N.Y., 1991).

Thaler, R., The winner's curse: paradoxes and anomalies of economic life (New York, 1992).

Trivers, R. L., Social evolution (Menlo Park, Cal., 1985).

Twigg, J., ed., Carers: research and practice (1992).

Varese, F., 'Is Sicily the future of Russia? Private protection and the emergence of the Russian mafia', Archives Européennes de Sociologie, 35 (1994), pp. 224-58.

Wallerstein, J. S., 'The long-term effects of divorce on children: a review', f. Amer. Acad. Child $\mathcal{E}$ Adolescent Psychiatry, 30 (1991), pp. 349-60.

Wallis, J. J. and North, D. C., 'Measuring the transaction sector in the American economy: 18701970', in S. L. Engerman and R. E. Gallman, eds., Long-term trends in the American economy (Chicago, 1988).

Wallis, J. J. and North, D. C., 'Should transaction costs be subtracted from gross national product?', f. Econ. Hist., XLVIII (1988), pp. 651-4.

Waring, S. P., Taylorism transformed: scientific management theory since 1945 (Chapel Hill, N.C., 1995).

Webley, P. and Lea, S. E. G., 'The partial unacceptability of money in repayment for neighbourly help', Human Rel., 46 (1993), pp. 65-76.

Webley, P. and Wilson, R., 'Social relationships and the unacceptability of money as a gift', 7 . Soc. Psychol., 129 (1989), pp. 85-91.

Wellins, R. S., Byham, W. C., and Wilson, J. M., Empowered teams: creating self-directed work groups that improve quality, productivity, and participation (San Francisco, 1991).

Williamson, O.E., The economic institutions of capitalism: firms, markets, relational contracting (New York, 1985).

World Bank, Averting the old age crisis: policies to protect the old and promote growth (New York, 1984).

Yang, M., 'The gift economy and state power in China', Comp. Stud. Soc. \&o Hist., 31 (1989), pp. 25-54.

Zamagni, S., ed., The economics of altruism (Aldershot, 1995).

Zelizer, V.A. R., Morals and markets: the development of life insurance in the United States (New York, 1979).

Zelizer, V. A. R., Pricing the priceless child: the changing social value of children (Princeton, 1994).

Zelizer, V. A. R., The social meaning of money (New York, 1994).

Zill, N., Morrison, D. R., and Coiro, M. J., 'Long-term effects of parental divorce on parent-child relationships, adjustment, and achievement in young adulthood', F. Fam. Psychol., 7 (1993), pp. 91-103.

\section{Official publications}

Great Britain, Census 1981, National Report: Great Britain, part I (1983).

Great Britain, Department of Health, Health and personal social services statistics for England, 1994 edition (1994).

United States Bureau of Census, Statistical abstract of the United States, 1989 (Washington, D.C., 1989).

United States Senate committee on interstate and foreign commerce, automobile marketing subcommittee, Automobile price labeling, hearings, 85 Congress, 2nd Session (1958) [Y4.I.8/3:Au8/4]. 